San Jose State University

SJSU ScholarWorks

Master's Theses

Master's Theses and Graduate Research

Summer 2017

\title{
Unravelling the paleotopography and extent of Eocene-Oligocene gravel deposition by ancient Sierran drainage systems
}

Christina Marie Tipp

San Jose State University

Follow this and additional works at: https://scholarworks.sjsu.edu/etd_theses

\section{Recommended Citation}

Tipp, Christina Marie, "Unravelling the paleotopography and extent of Eocene-Oligocene gravel deposition by ancient Sierran drainage systems" (2017). Master's Theses. 4864.

DOI: https://doi.org/10.31979/etd.28nz-7ha3

https://scholarworks.sjsu.edu/etd_theses/4864

This Thesis is brought to you for free and open access by the Master's Theses and Graduate Research at SJSU ScholarWorks. It has been accepted for inclusion in Master's Theses by an authorized administrator of SJSU ScholarWorks. For more information, please contact scholarworks@sjsu.edu. 


\title{
UNRAVELLING THE PALEOTOPOGRAPHY AND EXTENT OF EOCENE- OLIGOCENE GRAVEL DEPOSITION BY ANCIENT SIERRAN DRAINAGE SYSTEMS
}

\author{
A Thesis \\ Presented to \\ The Faculty of the Department of Geology \\ San José State University \\ In Partial Fulfillment \\ of the Requirements for the Degree \\ Master of Science
}

by

Christina M. Tipp

August 2017 
Christina M. Tipp

ALL RIGHTS RESERVED 
The Designated Thesis Committee Approves the Thesis Titled

\begin{abstract}
UNRAVELLING THE PALEOTOPOGRAPHY AND EXTENT OF EOCENEOLIGOCENE GRAVEL DEPOSITION BY ANCIENT SIERRAN DRAINAGE SYSTEMS
\end{abstract}

by

Christina M. Tipp

APPROVED FOR THE DEPARTMENT OF GEOLOGY

SAN JOSÉ STATE UNIVERSITY

August 2017

$\begin{array}{ll}\text { Emmanuel Gabet, Ph.D. } & \text { Department of Geology } \\ \text { Robert Miller, Ph.D. } & \text { Department of Geology } \\ \text { Kimberly Blisniuk, Ph.D. } & \text { Department of Geology }\end{array}$ 


\begin{abstract}
UNRAVELLING THE PALEOTOPOGRAPHY AND EXTENT OF EOCENEOLIGOCENE GRAVEL DEPOSITION BY ANCIENT SIERRAN DRAINAGE SYSTEMS
\end{abstract}

\author{
by Christina M. Tipp
}

The Tertiary gravels deposited along the western flank of the Sierra Nevada mountains elucidate the nature of the paleochannels and paleotopography of the range in the Eocene-Oligocene epochs. Numerous geologic maps and studies were compiled to place existing Tertiary gravels onto topographic maps and cross-sections extracted from ArcGIS. Based on the remnant deposits, the extent of deposition of the gravels during the Eocene-Oligocene epoch was inferred, and average end-area values were measured from the cross-sections to calculate the volume of the Tertiary gravels that was originally deposited. The map of the inferred deposits was also used to measure surface gradients of the gravels and compare them to deposits of active fluvial systems. This study calculated that 197-290 $\mathrm{km}^{3}$ of gravels were originally deposited and that surface gradients ranged from 0.004 to $0.034\left(0.229^{\circ}\right.$ to $\left.1.95^{\circ}\right)$. The map shows that the gravels were widely distributed across the west sloping ramp of the north and central Sierras, and the cross-sections suggest that the river valleys were deeply incised and filled with Tertiary gravels. The early Cenozoic Sierran landscape consisted of a tall, rugged mountain range carved by paleochannels that were subsequently buried by gold-bearing gravels during the Eocene and Oligocene epochs. 


\section{ACKNOWLEDGMENTS}

My thesis and master’s degree has been an educational journey and I want to thank my advisor, Dr. Emmanuel Gabet, for his knowledge, patience, and guidance over the years. Romig Engineers, Inc., specifically Glenn Romig, has been supportive of my path for higher education and assisted in funding my tuition in graduate school. My family has provided endless encouragement, love, and camping adventures and this would not be possible without all of you Sichley and Tipp family members. My sister Sara Sichley assisted me in the field and helped me with formatting and editing, thank you sis! Lastly, I would like to thank my husband, Kyle Tipp, who wears many hats in my life. He’s my field assistant, chef, computer tech, the father of our baby, Ronin, and the person that continually urges me to chase any dream I can imagine. 
TABLE OF CONTENTS

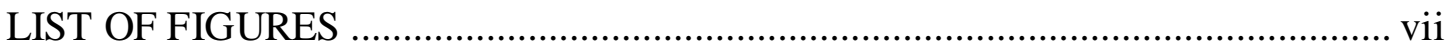

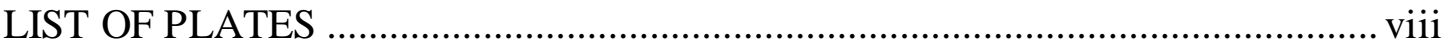

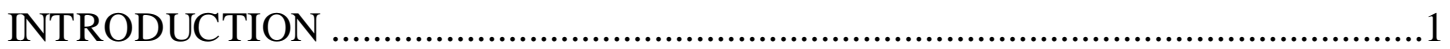

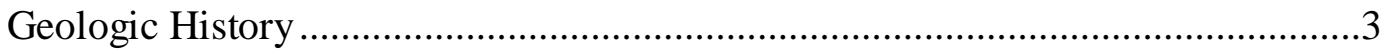

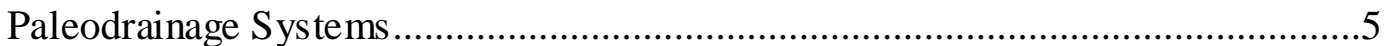

Stratigraphy of the Eocene-Oligocene Gravels...................................................

Provenance Analysis and Drainage Divide Migration........................................10

Tertiary Channel Reconstruction ................................................................

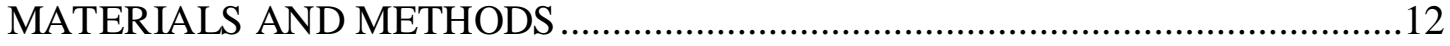

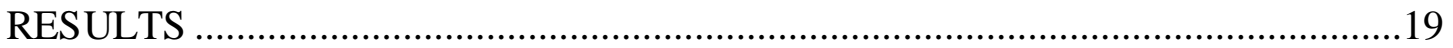

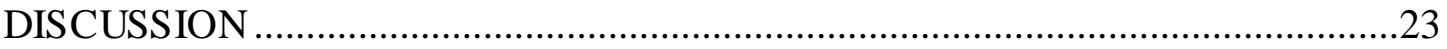

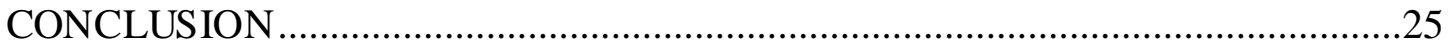

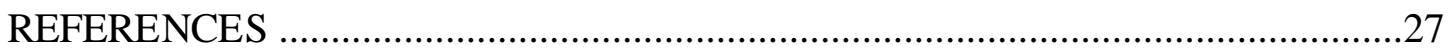




\section{LIST OF FIGURES}

Figure 1. $\quad$ Regional map showing California and adjacent states.........................2

Figure 2. $\quad$ Lindgren's (1911) reconstruction compared to this study ....................

Figure 3a. Simplified cross-section locating extant Tertiary gravels....................16

Figure 3b. Simplified cross-section illustrating inference of gravel deposits .......17

Figure 3c. Cross-section to explain order of deposition.....................................17

Figure 3d. Cross-section illustrating inference of gravels beneath ridges.............18

Figure 3e. Cross-section showing gravel cut off based on guidelines ..................18

Figure 3f. Cross-section showing inferred deposits on sloping topography.........19

Figure 4a. Cross-section extending across the North Yuba River .......................20

Figure 4b. Cross-section extending across the Middle and South Yuba Rivers ...21

Figure 4c. Cross-section extending across the North Fork American River.........22 


\section{LIST OF PLATES}

Plate 1. Map of remnant and inferred Eocene-Oligocene gravel deposits

Plate 2. Locations of surface gradient transects and cross-sections 


\section{INTRODUCTION}

To better determine the paleolandscape and timing of exhumation of the Sierra Nevada mountains an evaluation of the landscape is applied to understand the paleotopography, geomorphic evolution, and tectonic history of the dramatic mountain range extending along the majority of the state of California (Fig. 1). The western flank of the northern and central Sierras is presently riven by river valleys, which are thought by some to have experienced recent incision due to a pulse of late Pliocene uplift (Huber, 1981; Wakabayashi and Sawyer, 2001; Stock et al., 2004). In contrast, other studies present evidence suggesting that the Sierra Nevada mountains are an ancient range that have been an elevated topographic feature since the Cretaceous period (Wahrhaftig, 1965; Bateman and Wahrhaftig, 1966; DeGraaff-Surpless et al., 2002; Poage and Chamberlain, 2002; Cecil et al., 2006; Busby et al., 2008; Cassel and Graham, 2011;

Phillips et al., 2011; Cassel et al., 2012a; Gabet, 2014). Because the history of the Sierra Nevada mountain range during the Cenozoic era is poorly understood, studying its ancient rivers and fluvial deposits may help elucidate the evolution of this landscape.

Information about the history of the range can be inferred from gold-bearing gravels, commonly referred to as Tertiary, auriferous, or Eocene-Oligocene gravels (Lindgren, 1911; Hudson, 1951; Durrell, 1966; Cassel and Graham, 2011), which are the preserved relicts of ancient river systems in the Sierras. Remnants of the Eocene-Oligocene goldbearing gravels are found along the western flank of the northern and central Sierran foothills, extending approximately $250 \mathrm{~km}$ north to south and ranging from 40 to $130 \mathrm{~km}$ in the east to west direction (Fig. 1). Interest in the gold-bearing gravels began in the 


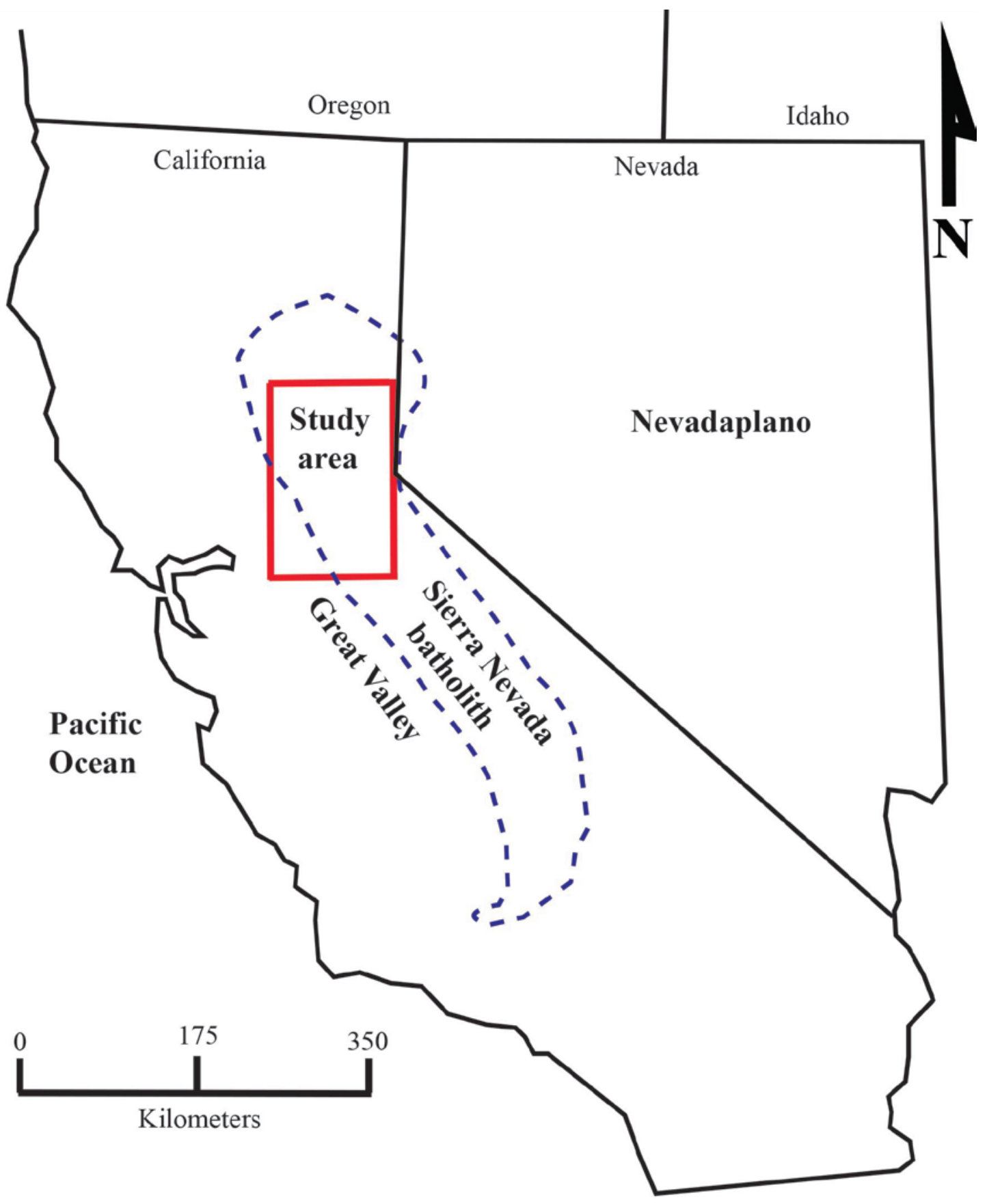

Figure 1. Regional map showing California and adjacent states. The red box frames the study area of the northern and central Sierras where the EoceneOligocene gravels were deposited. The dashed line outlines the Sierra Nevada batholiths and the Nevadaplano is shown to the east of the study area. 
mid-1800s with the discovery of high concentrations of placer gold found within these sediments (Lindgren, 1911; Bateman and Wahrhaftig, 1966; Durrell, 1966; Yeend, 1974). During the gold rush, hydraulic mining removed large amounts of auriferous gravels and left behind bare bedrock (Yeend, 1974). The occurrence and sources of the gold were evaluated in an effort to find profitable gold sources to mine, and thus, spurred numerous studies of the gravels (Lindgren, 1911; Bateman and Wahrhaftig, 1966; Peterson et al., 1968; Yeend, 1974). To calculate the abundance and likely profits at the different gravel localities, many studies estimated the volume of extant Tertiary gravels (Lindgren, 1911; Jarman, 1927; Peterson et al., 1968; Yeend, 1974). Lindgren (1911) recognized the inaccuracy of previous gold-bearing gravel volume estimates made by the army engineer whom included the volume of gravels from both hydraulic mining and drifting, which provided an "excessive” estimate. Due to the inaccuracy of the estimates, Lindgren (1911) estimated the volume of gravels firsthand by visiting remaining mined cavities and measuring gravel thicknesses. Peterson et al. (1968) estimated the volume of gravels exposed and buried between the Middle and South Yuba Rivers to be approximately 1.1 $\mathrm{x} 10^{8} \mathrm{~m}^{3}$. Jarman's (1927) study of the ancient Yuba River, extending from the North

Fork American River to the Middle Yuba River, estimated approximately 7 x $10^{8} \mathrm{~m}^{3}$ of gravel.

\section{Geologic History}

The auriferous gravels that were sought and mined during the gold rush were deposited primarily by northeast-to-southwest flowing channels and a few north-to-south flowing channels along the western flank of the Sierra Nevada range, with channel 
orientations constrained and influenced by lithology, structure, and differential weathering of the underlying Sierran bedrock (Cassel and Graham, 2011).

The Sierra Nevada mountain range has a complex geologic history that involves multiple intrusions, faulting, intense folding, foliation and lineation formation (Bateman and Wahrhaftig, 1966). The oldest rocks in the range are Precambrian and overlain by Paleozoic-Mesozoic-aged sedimentary, metasedimentary, and volcanic rocks along the western margin of the Cordilleran thrust belt (e.g., Bateman, 1992; DeCelles, 2004). Granitoids of the Sierra Nevada batholiths intruded these rocks above an east dipping subduction zone in the Late Jurassic to Late Cretaceous (e.g., Bateman, 1992; Ducea, 2001). Rocks west of the granitoid plutons formed four metamorphic belts, which are separated by reverse faults that dip steeply toward the east (e.g., Bateman, 1992). The rocks were uplifted and exhumed, although the uplift mechanism and timing remain a topic of discussion.

The unroofing rate of the Sierran arc during the Cretaceous period ranged from 0.35$1.0 \mathrm{~mm} / \mathrm{yr}$ (DeGraaff-Surpless, 2002); approximately 15-17 km of rock was removed from the Sierras at that time (Bateman and Wahrhaftig, 1966; Ague and Brimhall, 1988; DeGraaff-Surpless, 2002), creating a bare bedrock surface (Busby et al., 2008; Cassel and Graham, 2011). Based on the formation of lateritic soils, corestones, and grus, the exposed bedrock appears to have undergone long periods of chemical weathering (Bateman and Wahrhaftig, 1965; Wahrhaftig, 1966). Ancient Eocene-Oligocene rivers flowed down the western flank of the Sierran arc toward the ancestral Pacific Ocean and incised the underlying Paleozoic-Mesozoic bedrock, forming both steep-walled canyons 
and gently sloping valleys (Cassel et al., 2012a). A maximum gravel thickness of 140150 m was deposited in paleochannels (Lindgren, 1911; Peterson et al., 1968; Yeend 1974; Dickinson et al., 1979; Cassel and Graham, 2011) unconformably onto underlying basement rock west of the modern Sierra Nevada crest (Lindgren, 1911; Hudson, 1951; Cassel et al., 2011; 2012a; Henry et al., 2012).

\section{Paleodrainage Systems}

The channels that delivered the Tertiary gravels onto the western flank of the Sierras are difficult to study since their deposits have been mostly eroded and covered by volcanic rock; however, an in-depth study of a section of the deposits was performed by Cassel and Graham (2011) to assist in understanding the paleotopography and ancient

fluvial systems of the northern Sierra Nevada range. Studying the alluvial architecture revealed steep paleodrainages and moderate to high topographic relief outside of the drainages (Cassel and Graham, 2011). Their study concluded that steep creeks fed coarse-grained sediment to the broader main channels, and evidence for multiple periods of incision and valley widening followed by aggradation was found on the strath terraces within paleovalleys (Cassel and Graham, 2011).

Lindgren (1911) created a geologic map to show where he inferred the buried paleochannels and Tertiary gravels were located. The path of the ancient Yuba River is shown as a channel flowing from the northeast-to-southwest with multiple tributaries extending to the north and south from the main channel. The paleochannels shown on Lindgren’s (1911) geologic map are long, sinuous channels that connected the remnant Tertiary gravels, as shown on Fig 2. In contrast, a map by Henry (2009) showed the 
major paleovalley oriented from the northeast to the southwest with smaller tributaries extending toward the main channel in the downslope direction, similar to a dendritic drainage system. However, a more recent study by Cassel and Graham (2011) of the Eocene-Oligocene gravel deposits found that the gravels were not deposits characteristic of sinuous, meandering rivers through gentle topography as reported by Lindgren (1911) and Jones et al. (2004) and shown by Lindgren (1911) on Fig. 2.

Studies by Degraaff-Surpless et al. (2002) and Gabet (2014) suggest that the oldest identifiable drainage system was an Appalachian-style trellis network with longitudinal reaches extending along weak rocks and transverse reaches cutting across resistant rocks and flowing westward. Through knickpoint migration from the west, transverse channel reaches of the trellis network were captured and integrated into an east-west drainage system. Knickpoint migration, channel incision, and over-steepening of adjacent hillslopes supplied large quantities of sediment to the channels (Gabet, 2014). The drainage system was then buried by fluvial sediment, known as the Tertiary gravels (Lindgren, 1911), which collected behind greenstone and greenschist barriers in the Sierran foothills and aggraded from west-to-east (Cassel and Graham, 2011). The gravels were partially eroded before being buried by volcanic and volcaniclastic rock and debris, commonly known as the Mehrten and Valley Springs Formations, during a flurry of volcanic activity in the Oligocene to the Pliocene epochs (Durrell, 1966; Peterson et al., 1968; Saucedo and Wagner, 1992; Garside et al., 2005; Cassel et al., 2012a; Henry et al., 2012;). 


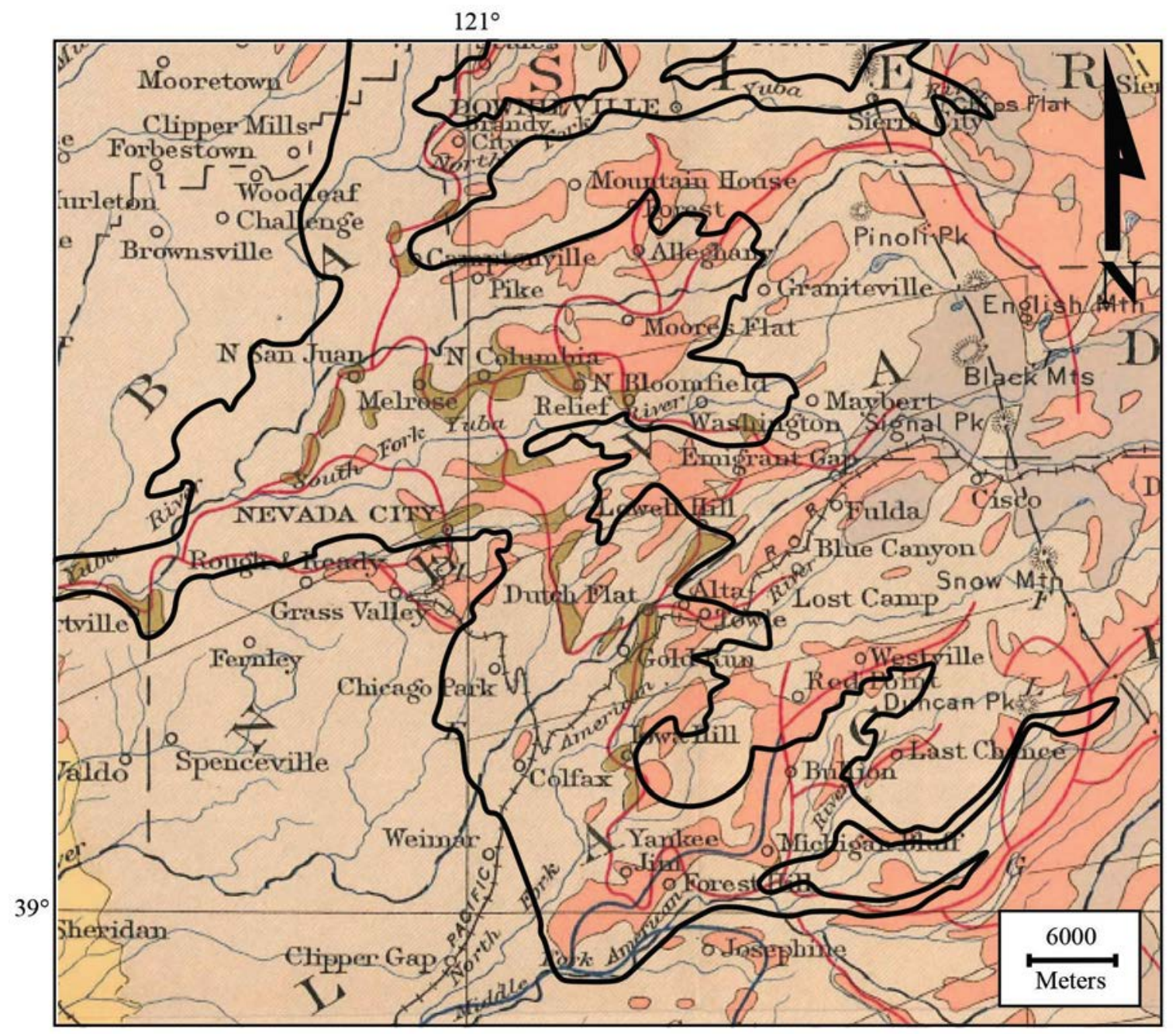

Figure 2. Lindgren's (1911) reconstruction compared to this study. Lindgren's (1911) auriferous Tertiary paleochannels (red lines), late Tertiary channels (blue lines), auriferous gravels (brown), granodiorite and quartz monzonite bedrock (light purple) and andesitic tuffs, andesite, basalt, and rhyolite bedrock (pink). The black line outlines the original deposition of the Eocene-Oligocene gravels as determined in this study in the vicinity of the North Yuba River southward to the Middle Fork American River.

\section{Stratigraphy of the Eocene-Oligocene Gravels}

To understand the nature of the Tertiary rivers, Cassel and Graham (2011) carefully analyzed the stratigraphy of the deposits. Particle sizes in the gold-bearing gravels 
ranged from clay to boulder and are representative of deposits from braided fluvial systems of variable energy (Cassel and Graham, 2011). The rounded boulders within the Tertiary gravels suggest steep and high energy fluvial systems (Bateman and Wahrhaftig, 1966; Cassel and Graham, 2011). The gravel deposits have fining upward sequences, which imply a decrease of both fluvial energy and capacity for sediment transport over time (Cassel and Graham, 2011).

Lindgren (1911) and Yeend (1974) divided the auriferous gravels into upper and lower units based on their stratigraphic composition and overall texture. The lower unit was described by Yeend (1974) as an imbricated, poorly sorted unit up to $43 \mathrm{~m}$ in thickness and containing boulders as large as $3 \mathrm{~m}$ in diameter. The poorly sorted, clast supported, pebble to boulder sized particles that comprise the disorganized lower gravel deposits suggest the material had not undergone significant transport (Lindgren, 1911; Cassel and Graham, 2011). The lower unit is blue-gray due to the occurrence of bluishgray slates and phyllites and reducing conditions below the water table and contains higher concentrations of gold, in comparison to the upper units (Yeend, 1974). The upper unit is comprised of more quartz clasts, silt to clay-sized grains, and heavy minerals of zircon, ilemenite, and magnetite, which distinguishes the upper from the lower units (Yeend, 1974). The upper gravels are fine-grained, reddish due to oxidation, overlain by rhyolitic and andesitic volcanic rocks, and up to approximately $120 \mathrm{~m}$ in thickness (Lindgren, 1911; Yeend, 1974).

For their study of the Eocene-Oligocene gravel deposits, Cassel and Graham(2011) divided the gold-bearing gravels into eight separate lithofacies based on particle size. 
The facies most common along steep, narrow channels, and generally only encountered in the lower portion of the gravel deposits was described as poorly sorted with imbricated gravel to boulder-sized sediment that may have traveled over $12 \mathrm{~km}$ from the suspected source rock (Cassel and Graham, 2011). The overlying coarse-grained facies were well sorted with weak stratification and generally found in wider paleovalleys deposited by channels with high energy discharge (Cassel and Graham, 2011). Finer-grained facies generally consisted of fine to coarse-grained sands varying from laminated to crossbedded or plane-laminated sands found in lenses or beds. These facies likely represent dune, channel bar, scour fill, and accretionary braided bar deposits (Cassel and Graham, 2011). The facies composing the upper portions of units consist of silt, silty clay, sandy clay, and fine sand deposits that fine upward (Cassel and Graham, 2011). The finest sediment was deposited by a low energy drainage system (Cassel and Graham, 2011).

The Ione Formation, dated as middle Eocene by molluscan fauna (Morris, 1966), is found along the western edge of the Eocene-Oligocene gravels with portions interfingered with the gravel deposits (Hudson, 1951; Durrell, 1966; Dickinson et al., 1979). The upper unit of the gold-bearing gravels and lower unit of the Ione Formation are of similar age and lithology and both contain similar heavy minerals (Lindgren, 1911; Bateman and Wahrhaftig, 1966; Yeend, 1974). The gravels appear to be the feeder source to the Ione Formation, which consists primarily of marine and non-marine sediments (Hudson, 1951; Cassel and Graham, 2011) or strictly non-marine sediment (Palmer, 1978; Palmer and Merrill, 1982). Sand grains and cobbles within the southernmost outcrop area of the Ione Formation were derived from volcanic and 
metamorphic sources (Palmer, 1978; Palmer and Merrill, 1982). Large crossbeds, megaripples, large and small troughs of channel bed deposits, planar beds consisting of clays, and silts interbedded with pebbly and gravelly beds are structures observed within the Ione Formation (Palmer, 1978; Palmer and Merrill, 1982). The stratigraphy suggests the formation was deposited primarily by braided streams with a component of alluvial fan and debris flow deposition (Palmer, 1978; Palmer and Merrill, 1982).

\section{Provenance Analysis and Drainage Divide Migration}

The gold-bearing gravels and the Ione Formation were deposited by paleochannels that likely extended beyond the modern drainage divide with headwaters in western Nevada (Durrell, 1966; Garside et al., 2005; Busby and Putirka, 2009; Cassel et al., 2012a; Henry et al., 2012; Mix et al., 2015). Lindgren (1911), in contrast, postulated that the headwaters of the paleochannels were west of the modern Sierran crest and thus, west of the current drainage divide. Provenance analysis of detrital zircons from the Sacramento Valley and the San Joaquin Valley suggests the drainage divide has migrated eastward through geologic time and uplift in the late Jurassic to early Cretaceous periods likely initiated this shift as channel heads eroded east into the range (DeGraaff-Surpless, 2002). Migration of the drainage divide presumably caused increased incision and expanded the channels' source areas, which led to the varying age range of zircons found in the study (DeGraaff-Surpless, 2002). Detrital zircon analysis of the auriferous gravels was also conducted by Cassel et al. (2012b) who reported that the bulk of the zircons were formed during the Mesozoic era and likely derived from the Sierran batholith. The study found that $5-20 \%$ percent of the zircons were created during the Precambrian to 
Paleozoic eras and 1-10\% of the zircons were created during the Jurassic period (Cassel et al., 2012b). The Jurassic-aged zircons may have been derived from the underlying basement rock or a region outside of the Sierras (Cassel et al., 2012b). Eocene-aged zircon grains, 33 to $55 \mathrm{Ma}$, found during the analysis were considered "extra-regional” because they were not derived from bedrock of the Sierras but from sources in Nevada (Cassel et al., 2012b). Eocene-Oligocene gravels near La Porte include chert pebbles that Durrell (1966) suggested were from rocks east of the modern-day Sierran range. The gold and “milky vein quartz" in the auriferous gravels likely eroded from mesothermal gold-bearing quartz veins near Placerville and Grass Valley with some gold deposits from paleo-placer deposits of copper-gold and quartz-tourmaline veins in western Nevada (Garside et al., 2005). Based on the age range of zircon grains, the occurrence of extraregional grains, and chert pebbles from Nevada, the channels that deposited the auriferous gravels reached beyond the current drainage divide (and modern day crest of the Sierra) into Nevada (Durrell, 1966; Cassel et al., 2012a; 2012b). Nevada is hypothesized to have been part of an elevated plateau (Garside et al., 2005) known as the “Nevadaplano” (DeCelles, 2004), which likely extended into Utah in the EoceneOligocene (Busby and Putirka, 2009).

\section{Tertiary Channel Reconstruction}

The locations and paths of Tertiary paleochannels were previously reconstructed to argue for late Cenozoic Sierran uplift (Lindgren, 1911; Jones et al., 2004); however, these studies are flawed for the following reasons. Lindgren (1911) reconstructed paleochannels by simply connecting adjacent remnant Tertiary gravel deposits and two 
paleochannels appear to gain elevation downstream as they extend up and over a ridge (Gabet, 2014). Earlier studies described the paleochannels as sinuous, meandering channels draining topographically gentle areas (Lindgren, 1911; Yeend, 1974; Jones et al., 2004) (Fig. 2). Peterson et al. (1968) and Yeend (1974) created maps showing the approximate paths of paleochannels in the localized area between the North Fork American River and the South Yuba River. My study aims to expand and improve upon former studies and included a comprehensive review of available data, including remnant exposures, geologic maps, and reported auriferous gravels from field investigations and prospecting shafts. The research was used to create a map (Plate 1, 2) and several crosssections showing the wide span of Eocene-Oligocene gravel deposition.

Previous workers (Lindgren, 1911; Peterson et al., 1968; Yeend, 1974) visited mines, shafts, hydraulic mining sites, and drifting locations to estimate the volume of extant gravels that could be mined economically for gold and evaluated the visible deposits and mined cavities (Lindgren, 1911; Yeend, 1974). This study is the first to estimate the original volume of auriferous gravels deposited by paleochannels in the EoceneOligocene. Therefore, allowing for the analysis of the paleotopography of the northern Sierra Nevada mountains and characterization of the ancient drainage system that spread across the Sierran landscape.

\section{MATERIALS AND METHODS}

Remnants of the Tertiary gravels are located in narrow drainages and along ridges of the northern half of the Sierran range, west of the modern drainage divide (Lindgren, 1911; Yeend, 1974; Wagner et al., 1981; Saucedo and Wagner, 1992; Garside et al., 
2005; Cassel et al., 2011). A compilation of geologic maps and studies (Lindgren, 1911; Peterson et al., 1968; Yeend, 1974; Hietanen, 1976; Wagner et al., 1981; Saucedo and Wagner, 1992; Garside et al., 2005; Cassel and Graham, 2011) were used to map extant Tertiary gravel deposits onto modern day topographic maps (Plate 1). The reconstruction of the inferred deposits was based on published geologic maps, reports, and exploratory data and, in many locations; the deposits were not large enough to show on geologic maps and are simply described in studies or by latitude and longitude (Hudson, 1951). Cross-sections across the northern Sierran foothills were extracted from digital elevation models (DEM) in ArcGIS, and the Tertiary gravels, Oligocene-Miocene volcanic rocks, and Paleozoic-Mesozoic bedrock units were overlain onto the cross-sections based on their locations and elevations on my map (Plate 1). The original extent of the deposits was inferred by extending them across channels, valleys, and low-lying ridges, which provided a depositional reconstruction of the Eocene-Oligocene gravels. Inference of the gravel deposition laterally and vertically on the map with cross-sections provides a threedimensional model of the deposits, which assisted in estimating the thickness, volume, orientation, and flow patterns of the drainage system. The reconstruction was used to present both the minimum lateral extent of the deposits and minimum and maximum volumes of the gold-bearing gravels deposited during the Eocene-Oligocene epochs. Auriferous gravel deposits, too limited to significantly affect the total volume, exist beyond the limits of the map (Plate 1) and were not included in this study.

To reconstruct the original extent of the gravels, the following guidelines were applied: 
1. Existing deposits mapped along one side of a valley were inferred to extend across the valley at identical elevations (Fig. 3a, b). This guideline assumes that there has not been significant tilting of the range along an east-west axis.

2. Inferred deposits were not placed at elevations higher than the elevation of the highest mapped deposit in the immediate vicinity, within a channel, or as encountered in a nearby shaft. Inferred deposits were not placed at elevations lower than the nearest, lowest mapped deposit. The exception to this guideline is when calculating the maximum volume of gravels deposited within the main Sierran valleys, which were already deeply incised by Eocene-Oligocene times (Gabet, 2014). In this case, the gravels were inferred to extend to the bottom of the Yuba, American, Feather, Mokelumne, Calaveras, and Tuolomne canyons, below the elevation of the lowest remnant gravel deposits.

3. Eocene-Oligocene gravels are stratigraphically above Paleozoic- and Mesozoicaged rock and below the Oligocene- and Miocene-aged volcanic rock. Since the gravels were deposited prior to the volcanic rocks, there are instances where gravels on the cross-sections appear to extend above and through the volcanic rocks (Fig. 3c).

4. Deposits found at similar elevations on each side of a ridge capped by Oligocene to Miocene rhyolite and andesite tuffs are assumed to extend across the ridge beneath the volcanic rocks (Fig 3d). Exploratory boreholes, shafts, and quarries on ridges and beneath rhyolite and andesite tuffs and colluvium during the gold rush encountered auriferous gravels tens to hundreds of meters beneath the 
ground surface. San Juan Ridge, Bunker Hill, Port Wine Ridge, Mooreville Ridge, Georgia Hill, Todd Valley, and the ridge north of Smith Flat are examples where there are no exposed gravel deposits on the ridge; however, boreholes and shafts encountered gold bearing gravels at depth (Lindgren, 1911; Peterson et al., 1968) (Plate 1).

5. In three instances, the gravel deposits extended above ridges of PaleozoicMesozoic rocks located downslope and, in those cases, the gravels were cut off and not extended over the landscape. When the downslope ridges were situated below the gravel deposits a cut off was applied to the nearest, easternmost ridge within $100 \mathrm{~m}$ from the top of the gravel deposits (Fig. 3e). Locations where these instances were observed include ridges between the North Fork American and Middle Fork American, North Yuba River and Oregon Creek, and Weber Creek and Squash Hollow Creek (Plate 1). Terminating the gravels at the nearest ridge, within $100 \mathrm{~m}$ of the gravel deposits, rather than extending the deposits to completely bury the entire landscape, provides a conservative volume estimate of the Eocene-Oligocene gravels and a limit to their depositional boundary.

6. The deposits are assumed to be continuous and fairly uniformly sloped along their basal and surface boundaries with no topographic breaks. Deposits at higher elevations were extended to the top of deposits located downslope. This reasoning also applies to the basal surface of the Eocene-Oligocene gravels by extending the deposits down-valley to the gravel deposit located at the lowest elevation (Fig. 3f). 
The map of the inferred gravel deposits was used to extrapolate the location and elevations of the deposits and show them on cross-sections taken along several transects across and along the length of the deposits (Plate 2). The cross-sections show the varying thickness of the gravels in the river valleys and the area of the gravel deposits was measured from the cross-sections. The area of the gravel deposits was averaged with the nearest adjacent section line and multiplied by the distance between the sections, providing average end-area values. The average end-area values were summed to provide the approximate volume of gravels deposited during the Eocene-Oligocene epochs within the study area.

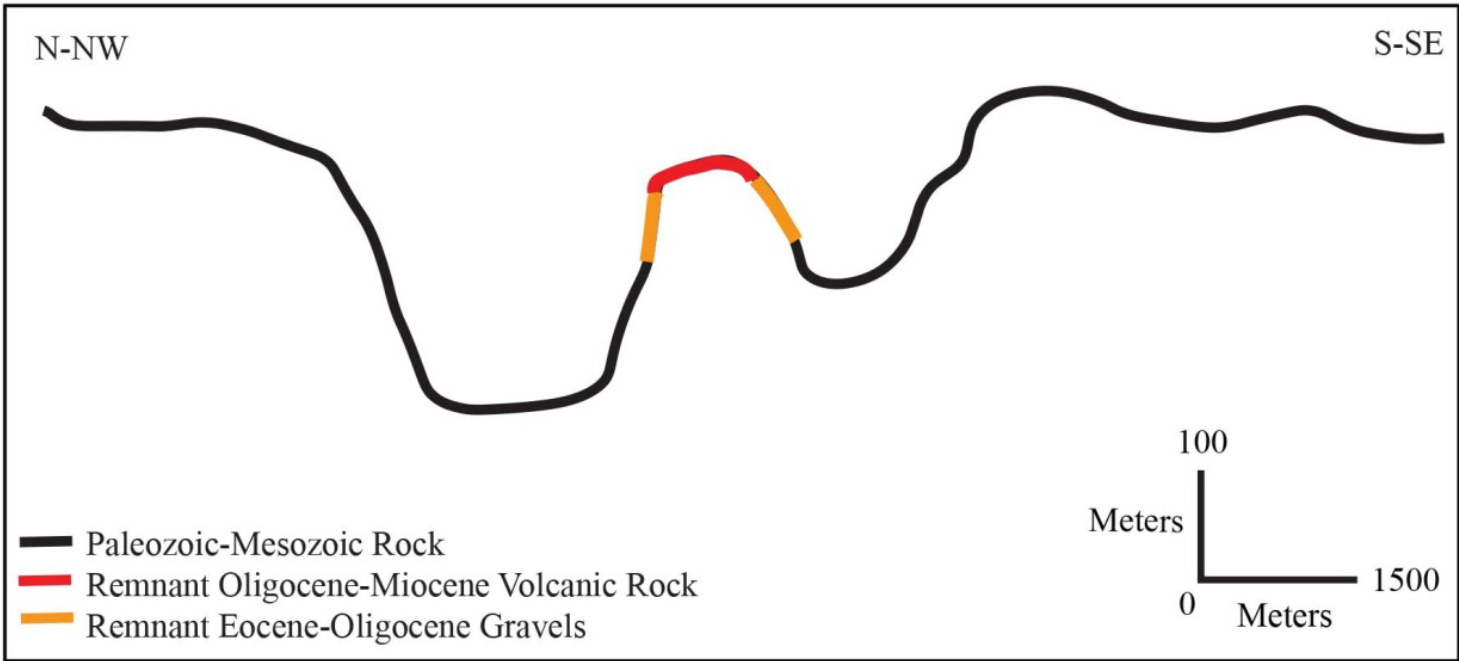

Figure 3a. Simplified cross-section locating extant Tertiary gravels. PaleozoicMesozoic bedrock (black line) with existing Eocene-Oligocene aged gravel deposits (orange line) and Oligocene-Miocene aged volcanic rock (red line) mapped along a simplified cross-section illustrating valleys and ridges of the Sierras. 


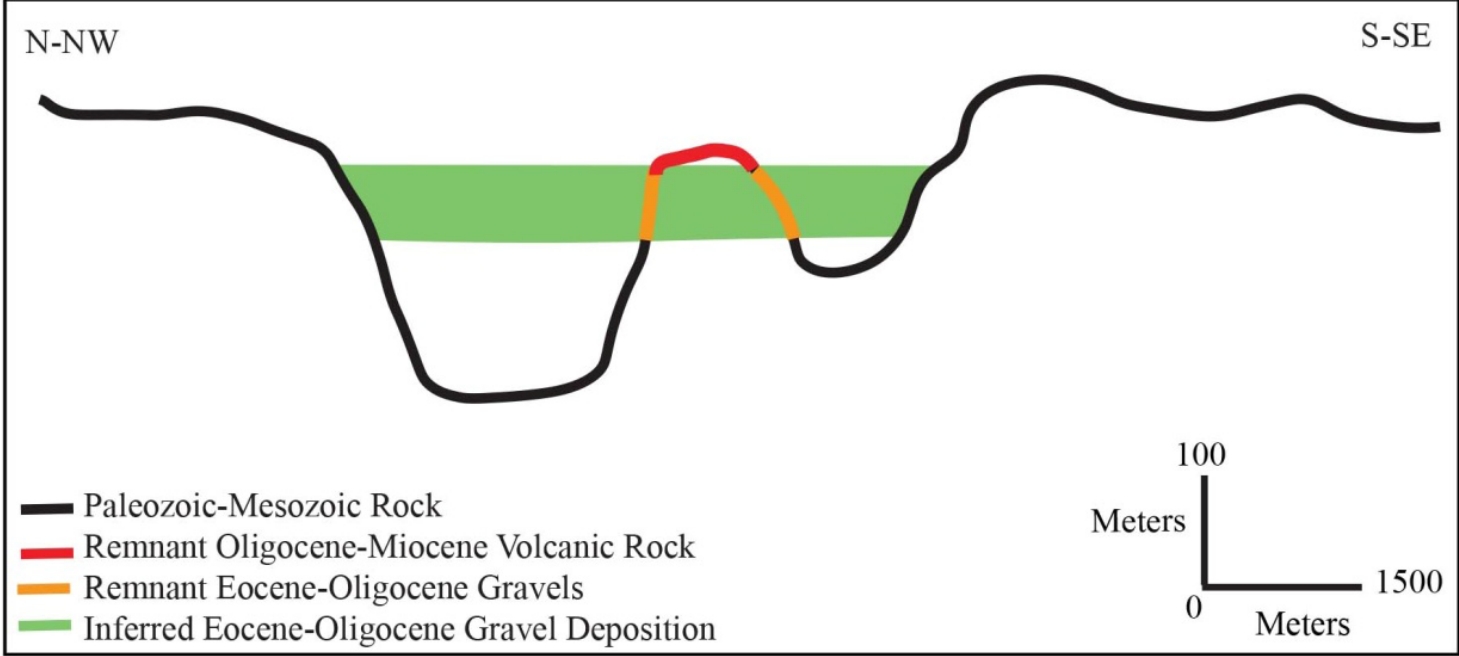

Figure 3b. Simplified cross-section illustrating inference of gravel deposits. The inferred original extent of deposition of Eocene-Oligocene gravels (green shading) extending between extant gravel deposits, across valleys, and beneath ridges of volcanic rock. The cross-sections were used to estimate the gravel volume.

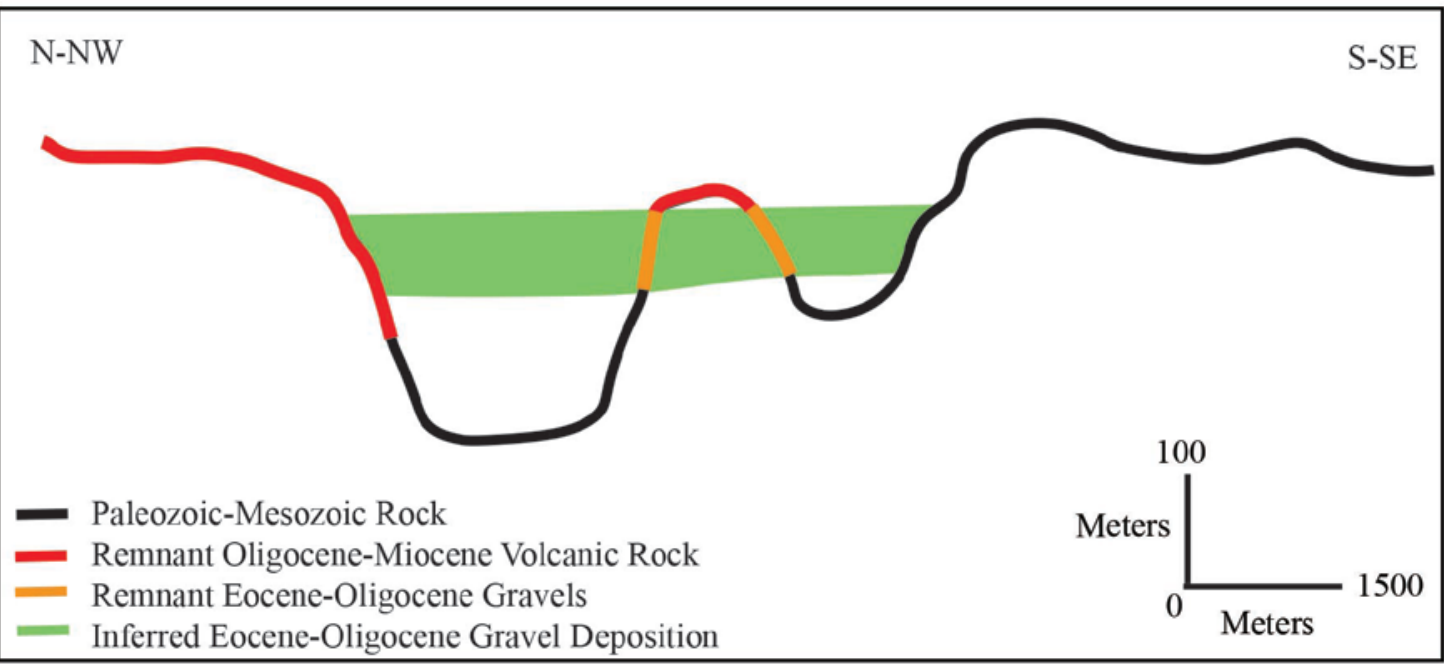

Figure 3c. Cross-section to explain order of deposition. Eocene-Oligocene gravels were deposited and partially eroded prior to deposition of the Oligocene-Miocene volcanic rock thus; gravel deposits were inferred to extend through or over the volcanic rock. 


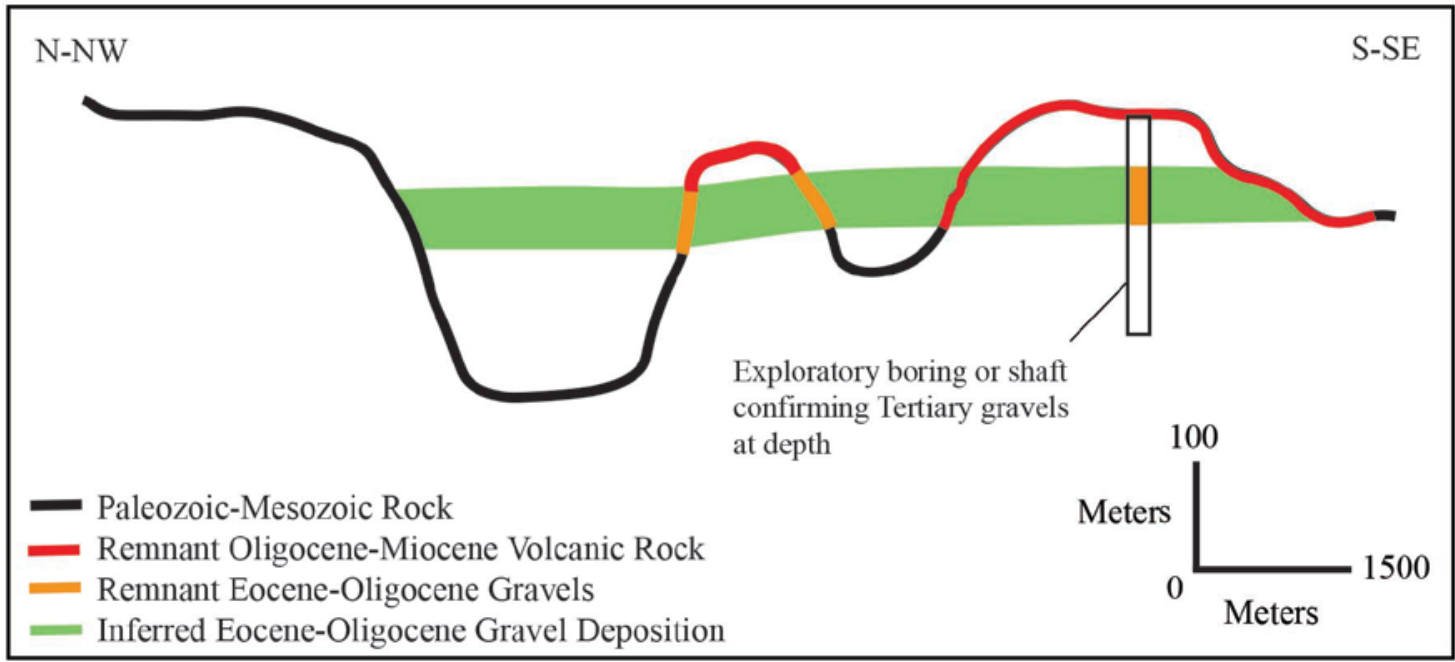

Figure 3d. Cross-section showing inference of gravels beneath ridges. EoceneOligocene gravel deposits were extended below ridges when shafts or exploratory borings (shown as black vertical rectangle through ridge) from previous studies confirm the presence of the gravel deposits at depth. The map (Plate 1) does not show deposits under the ridges capped by volcanic rocks; however, the buried gravels were included in the volume calculations.

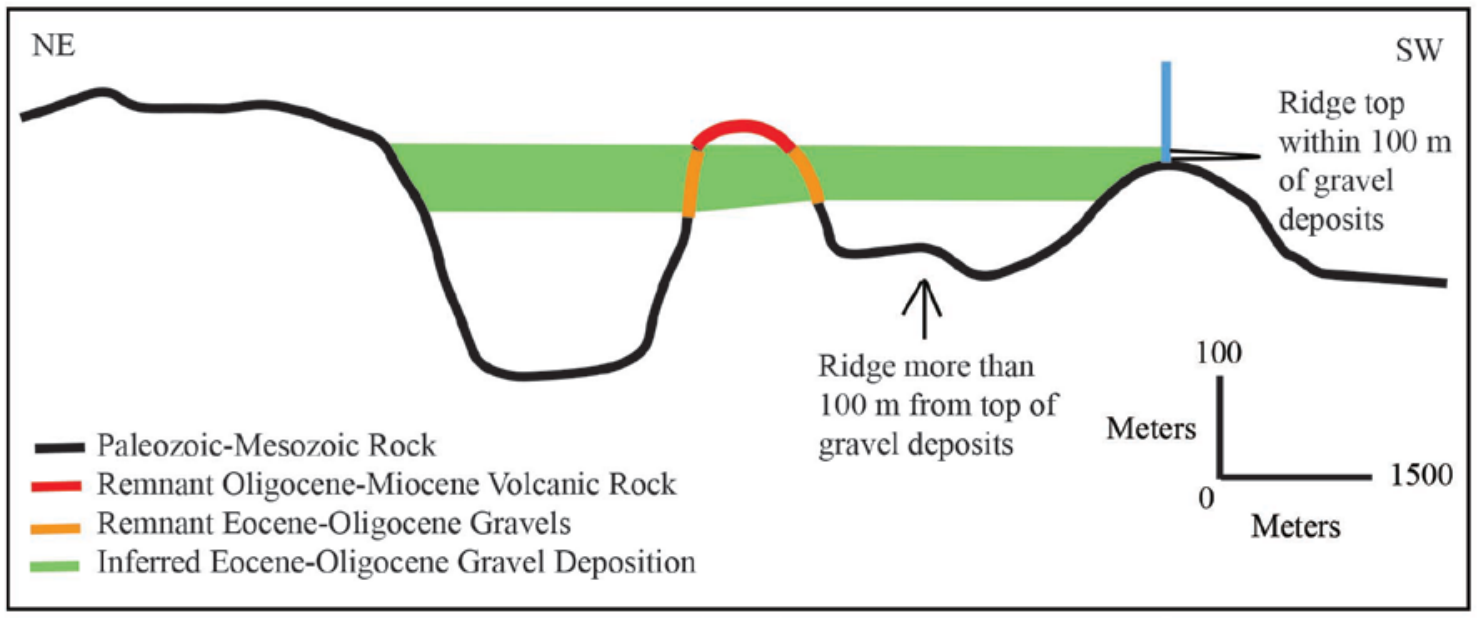

Figure 3e. Cross-section showing gravel cut off based on guidelines. When the original Eocene-Oligocene gravel deposits extended above all ridges located downslope, the gravel deposits where inferred to extend to the top of the nearest ridge within a vertical length of 100 meters of the top of the inferred deposits. The vertical blue line represents where the deposits were cut off. This provides a conservative estimate of the extent of the deposits. 


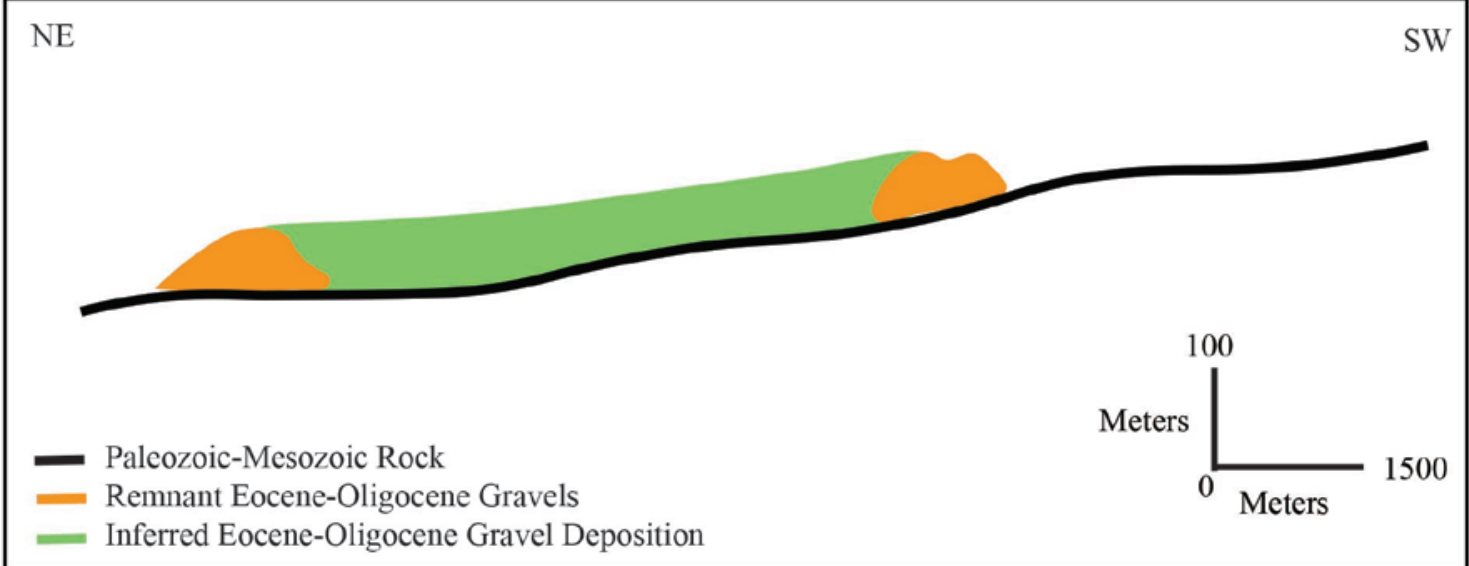

Figure 3f. Cross-section showing inferred deposits on sloping topography. Inferred deposits were extended downslope to the top of the next gravel deposit. Surface slope measurements were collected from the top of the deposit with the highest elevation down to the top of the deposit at the lowest elevation.

The reconstruction was also used to calculate the surface gradients of the originally deposited gravels and to compare those values to published gradients of alluvial fans, braided rivers, and meandering rivers. The seven slopes of northeast-southwest-oriented transects were determined across the length of the Eocene-Oligocene gravel deposits from higher to lower elevations (Plate 2).

\section{RESULTS}

The summary reconstruction map (Plate 1) depicts both the modern-day locations of auriferous gravels and the inferred extent of gravel deposition during the EoceneOligocene epochs. Based on the reconstruction, the auriferous gravels were deposited at elevations ranging from 204 m (670 feet) at New Hogan Reservoir up to 2,133 m (7,000 feet) at Haven Lake (Plate 1). Cross-sections show deeply incised river valleys and thick 
gravel deposits across the landscape. The North, Middle, and South Yuba Rivers and North Fork American River were deeply incised during the Eocene and Oligocene epochs based on the Tertiary gravels present within the river valleys (Fig. 4a, 4b, 4c). The preTertiary landscape was a rugged west sloping ramp carved by numerous incised rivers.

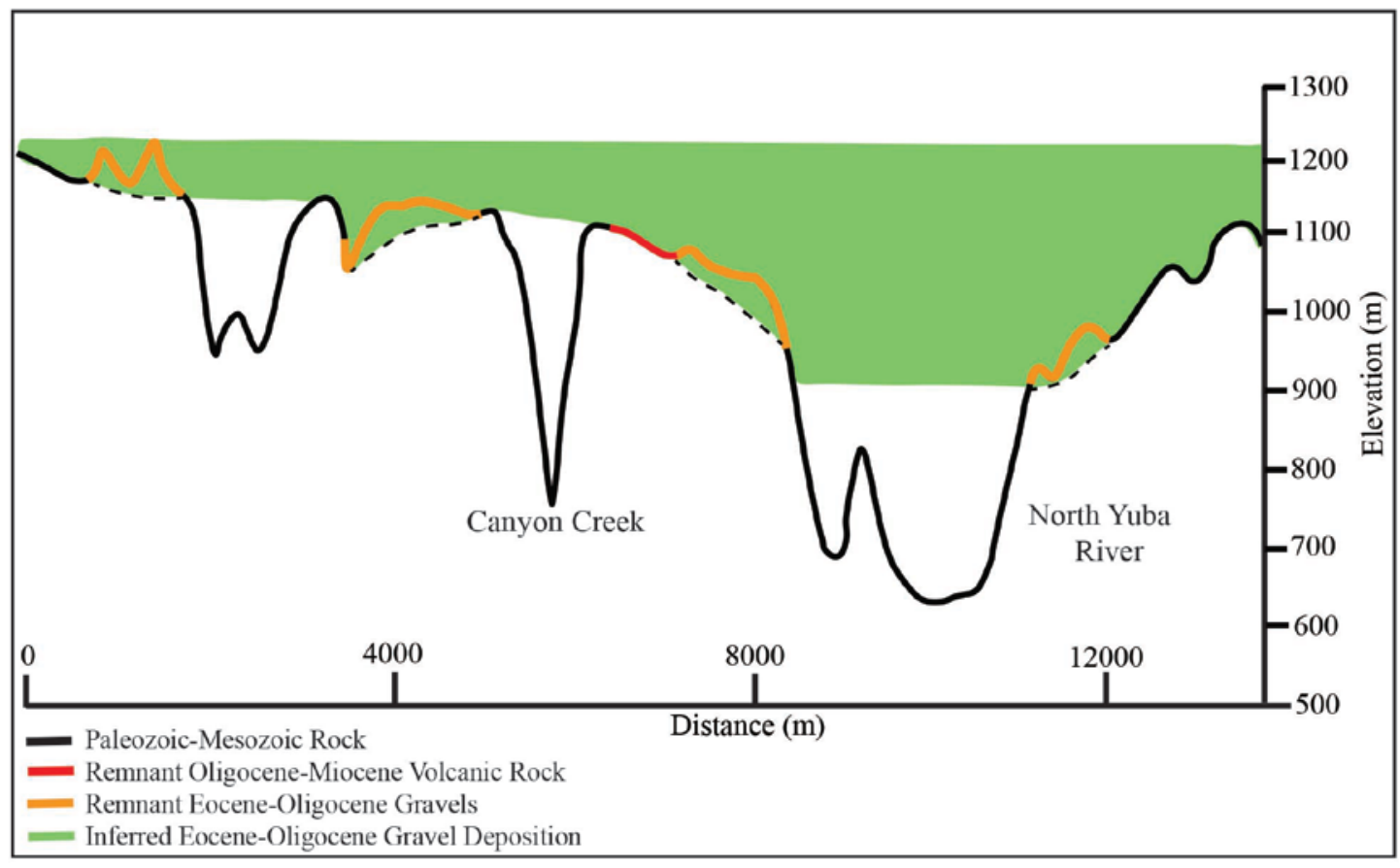

Figure 4a. Cross-section across the North Yuba River. The North Yuba River is deeply incised in the Eocene-Oligocene and remnants of Tertiary gravels (orange lines) can be observed within the river valley. The inferred deposits (green shading) are shown only extending to the elevation of the lowest deposit, representing the minimum volume of gravels deposited. The dashed lines represent the inferred basal surface of the Tertiary gravels. 


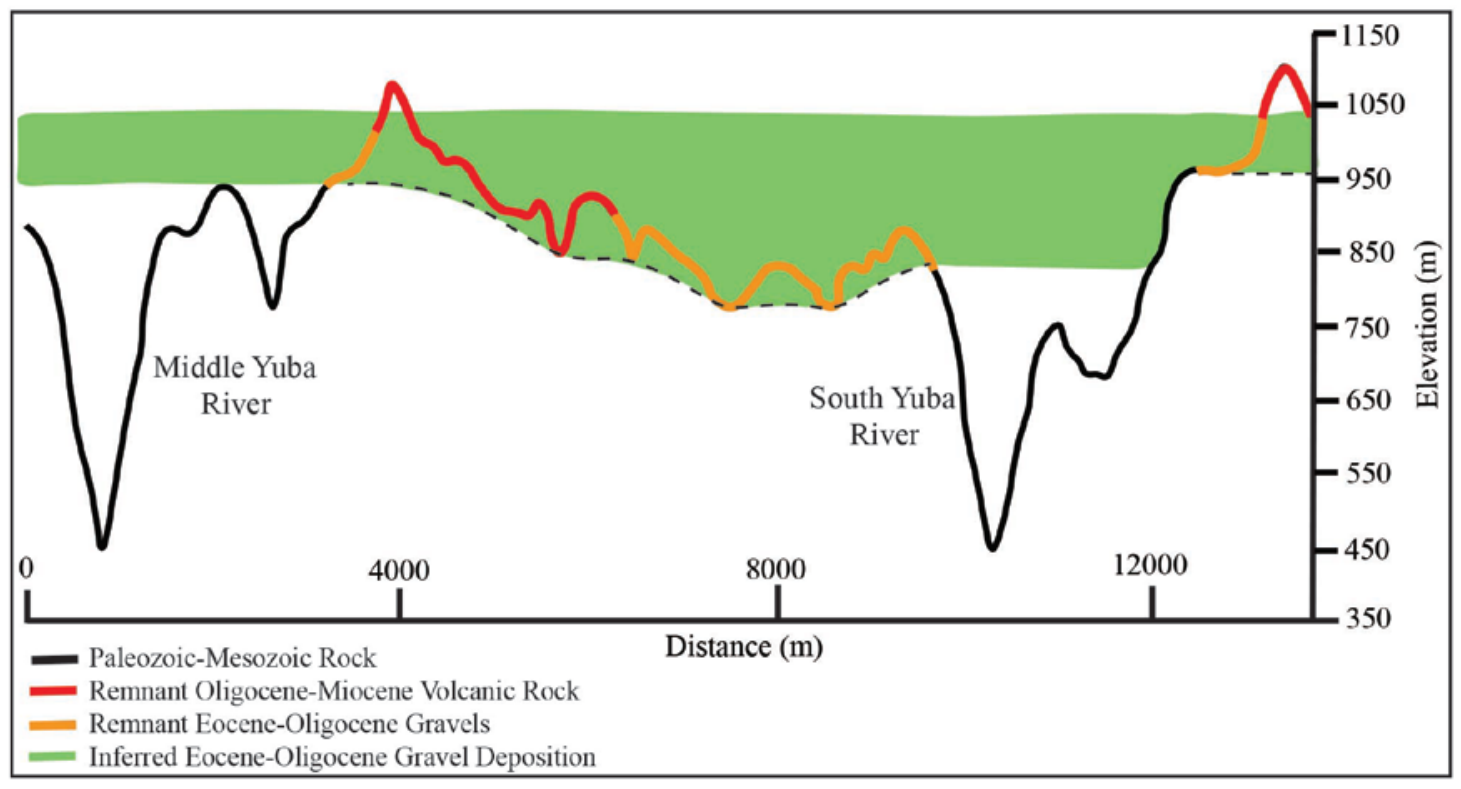

Figure 4b. Cross-section across the Middle and South Yuba Rivers. Note the incision depths of both rivers. The dashed lines represent the inferred basal surface of the Tertiary gravels.

The drainage systems responsible for transport and deposition of the gravels spanned vast areas across the western slope, and the deposits were not constrained to singular, meandering channels as Lindgren (1911) and Jones et al. (2004) assumed; rather, the deposits appear to have been formed primarily by deposition from braided channels (Cassel and Graham, 2011). The westward reaches of the rivers were unable to efficiently transport sediment through the greenstone ridges of the Sierra Nevada foothills; either the canyons extending through the ridges were too narrow and acted as chokepoints that inhibited the passage of sediment or a reverse fault created a lowgradient section that impeded sediment transport (Cassel and Graham, 2011). In both cases, the ridges were structural features that acted as barriers to the ancient rivers 
(Lindgren, 1911; Cassel and Graham, 2011). Sediment aggradation behind the ridges is evident northeast and east of Auburn, between Gold Hill and Shingle Springs, and east of New Hogan Reservoir where the auriferous gravels were deposited east of northwest trending, Paleozoic and Mesozoic metamorphic and volcanic bedrock ridges (Wagner et al., 1981; Saucedo and Wagner, 1992). Where the rivers eroded and incised through the ridges, specifically near Oroville and Smartville, Tertiary gravels were deposited farther west (Cassel and Graham, 2011).

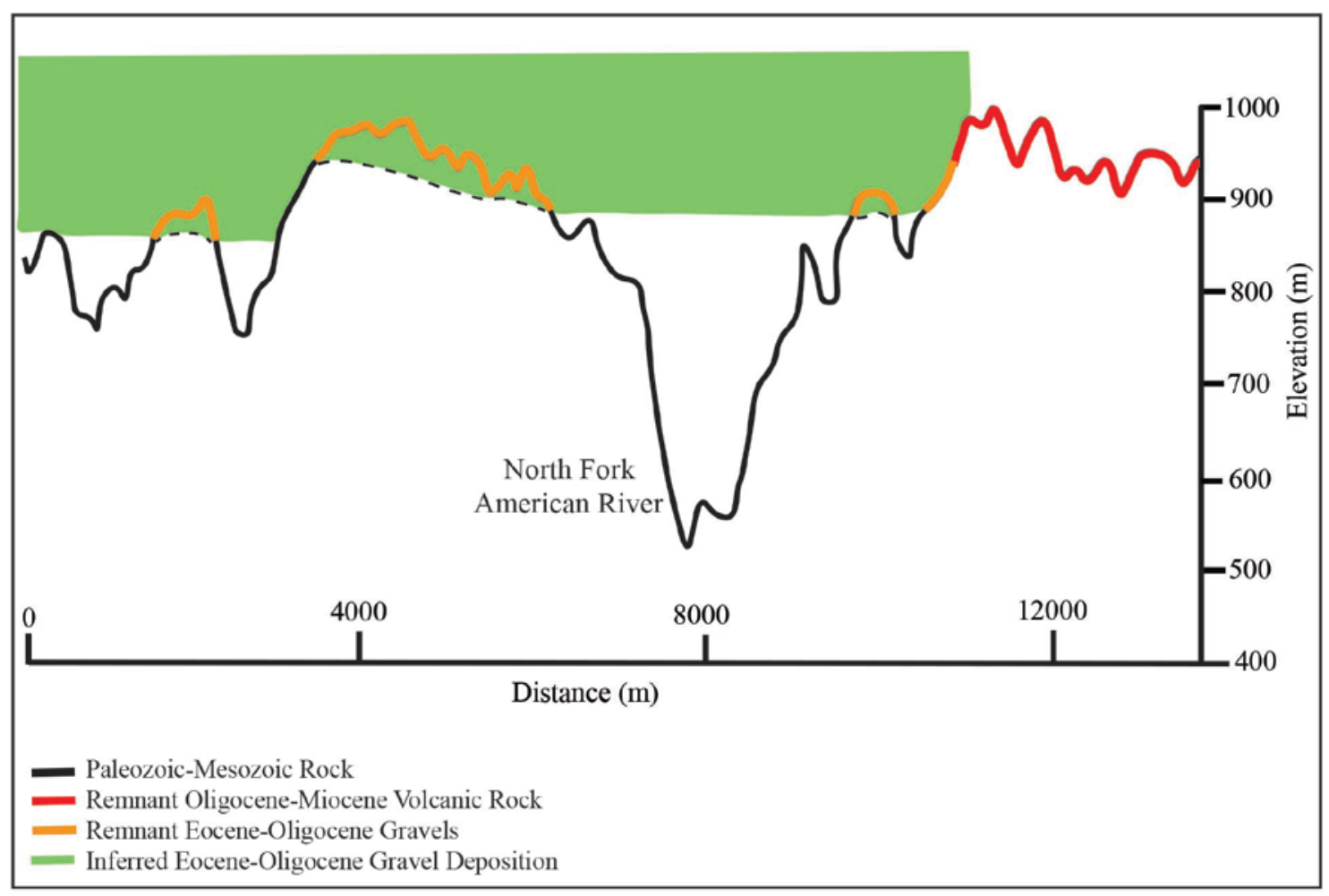

Figure 4c. Cross-section across the North Fork American River. The river is deeply incised and remnants of Tertiary gravels (orange lines) can be observed along the ridges. The inferred deposits (green shading) are shown only extending to the elevation of the lowest deposit, representing the minimum volume of gravels deposited. The top of the gravels (green shading) are located at the elevation of the deposits extending south from the Yuba Rivers, on previous figure. The dashed lines represent the inferred basal surface of the Tertiary gravels. 
The abundance of auriferous gravels is apparent when comparing the reconstruction from this study to previous geologic maps (Lindgren, 1911; Yeend, 1974; Wagner et al., 1981; Saucedo and Wagner, 1992). From the average end-area calculations, the approximate minimum and maximum volumes of gold-bearing gravels deposited during the Eocene-Oligocene epoch were $197 \mathrm{~km}^{3}$ and $290 \mathrm{~km}^{3}$, respectively.

The surface slopes of the deposits were calculated based on their elevations from the upslope eastern edge to their downslope western edge (Plate 2). The deposits had surface slopes ranging from 0.004 to $0.034\left(0.229^{\circ}\right.$ to $\left.1.95^{\circ}\right)$.

\section{DISCUSSION}

The calculated volumes of auriferous gravels $\left(197 \mathrm{~km}^{3}\right.$ and $\left.290 \mathrm{~km}^{3}\right)$ estimated here account for deposits buried beneath volcanic rock and colluvium and the original extent of the gold bearing gravels in the Eocene-Oligocene epoch (Plate 1). The minimum and maximum calculated volumes of the original deposits greatly surpass previous estimates of the remnant auriferous gravels, ranging from $0.11 \mathrm{~km}^{3}$ to $0.7 \mathrm{~km}^{3}$ (Lindgren, 1911 ; Jarman, 1927; Peterson et al., 1968; Yeend, 1974). The extent of the original gravels deposition was based on the locations and elevations of remnant deposits; however, portions of the original deposits have been eroded since the Eocene epoch.

My spatial reconstruction of the extent of the inferred gravel deposition followed specific guidelines, which limited the areal extent of the deposits shown on the map (Plate 1) and provided conservative estimates of the minimum and maximum values. These guidelines include terminating gravel deposits at downslope ridges that would otherwise extend the gravels over all downslope ridges, extending deposits across valleys 
at the same elevations of the existing deposits, and extending gravels beneath ridges where mining data confirmed gravels at depth or cross-sections indicated gravels were situated at similar elevations on either side of the ridge and were buried by volcanic rock.

The surface gradients of the deposits were measured to compare and contrast with deposits of active fluvial systems and paleoslope calculations of the Tertiary gravels by Cassel and Graham (2011). Slopes calculated from measurements on remnant EoceneOligocene gravels within the study area range from 0.004 to $0.055\left(0.2^{\circ}\right.$ to $\left.3.1^{\circ}\right)$ (Cassel and Graham, 2011). Stream gradients of gravel bed streams in Idaho range from 0.004 to $0.07\left(0.2^{\circ}\right.$ to $\left.4.0^{\circ}\right)$ (Whiting et al., 1999). Gradients of aggrading alluvial fans range from 0.008 to $0.02\left(0.4^{\circ}\right.$ to $\left.1.1^{\circ}\right)$ (Blair and McPherson, 1994) and have been measured to have slopes as steep as 0.052 to $0.087\left(2.9^{\circ}\right.$ to $\left.4.9^{\circ}\right)$ in active tectonic environments (Blair, 2000). The surface slope of braided rivers with gravel deposits ranges from 0.016 to $0.024\left(0.1^{\circ}\right.$ to $\left.1.3^{\circ}\right)$ (Paes de Almeida et al., 2016). The slopes of single thread meandering channels are gentler slopes ranging from 0.002 to $0.008\left(0.1^{\circ}\right.$ to $\left.0.4^{\circ}\right)$ (Paes de Almeida et al., 2016). The surface gradients of the reconstructed gravel deposits from this study ranged from 0.004 to $0.34\left(0.2^{\circ}\right.$ to $\left.1.9^{\circ}\right)$, similar to the gradients of remnant Tertiary gravels calculated by Cassel and Graham (2011), active alluvial fan and coarsegrained braided rivers measured by Blair and McPherson (1994) and Blair (2000), and stream gradients of modern gravel bedded streams (Whiting et al., 1999). Furthermore, the Eocene-Oligocene gravels are poorly sorted, contain large grain sizes, include both channel bar and channel fill deposits, and are laterally continuous, which are all characteristics of braided streams (Whiting et al., 1999; Cassel and Graham, 2011). 
The Eocene-Oligocene auriferous gravels buried the pre-Eocene channels that had already cut deeply into the Sierran landscape (Cassel and Graham, 2011; Gabet, 2014) and blanketed valleys and ridges composed of Paleozoic and Mesozoic bedrock. The reconstruction presented here demonstrates that the gravel deposits were not constrained within single channels and the paleochannels did not simply extend from one gravel deposit to the next as assumed by Lindgren (1911). Detailed analysis of the EoceneOligocene gravel stratigraphy indicates the deposits are remnants of braided drainage systems that flowed toward the west into the Great Valley where the gravels interfingered with the Ione Formation (Bateman and Wahrhaftig, 1966; Cassel and Graham, 2011). The sedimentary structures of the Ione Formation, situated along the western edge of the Tertiary gravels, also suggest deposition by braided streams (Palmer, 1978; Palmer and Merrill, 1982).

Approximately 1-20\% of the Tertiary gravel deposits were sourced from Nevada (based on detrital zircon analysis); thus, paleodrainages likely had headwaters extending into the Nevadaplano (Garside et al., 2005; Cassel and Graham, 2011; Cassel et al., 2012b). The Nevadaplano was a plateau as high as the elevated Sierra Nevada range (Cassel and Graham, 2011), implying that the Sierran drainage divide was situated further to the east than previously thought.

\section{CONCLUSION}

The northern and central Sierran landscape was an elevated range dominated by steep paleodrainages that deposited approximately 197 - $290 \mathrm{~km}^{3}$ of gravels during the EoceneOligocene epoch. The stratigraphy and sedimentology of the gravels reflect fluvial 
transport by high energy braided stream systems. The surface gradients estimated from the reconstruction are within the average range of alluvial fan and braided drainage systems; thus, the western flank of the Sierras did not require uplift (from the Eocene epoch to the present day) to create the measured surface gradients of the gravels, as others have proposed (Huber, 1981; Wakabayashi and Sawyer, 2001; Stock et al., 2004). The Sierra Nevada range was already a tall range in the Eocene with stream channels depositing gravels that buried the pre-Tertiary Sierran landscape. 


\section{REFERENCES}

Ague, J. J. and Brimhall, G. H., 1988, Magmatic arc asymmetry and distribution of anomalous plutonic belts in the batholiths of California: Effects of assimilation, crustal thickness, and depth of crystallization: Geological Society of America Bulletin, v. 100, p. 912-927.

Bateman, P. C. and Wahrhaftig, C., 1966, Geology of the Sierra Nevada, in Bailey, E. H., editor, Geology of Northern California: California Division of Mines and Geology Bulletin 190, p. 107-172.

Blair, T. C., and McPherson, J. G., 1994, Alluvial fans and their natural distinction from rivers based on morphology, hydraulic processes, sedimentary processes, and facies assemblages: Journal of Sedimentary Research, v. 64, p. 451-490.

Blair, T. C., 2000, Sedimentology and progressive tectonic unconformities of the Sheet flood-dominated Hell's Gate alluvial fan, Death Valley, California: Sedimentary Geology, v. 132, p. 233-262.

Busby, C. J., DeOrea, S. B., Skilling, I., Gans, P. B., and Hagan, J. C., 2008, Carson Pass-Kirkwood paleocanyon system: Paleogeography of the ancestral Cascades arc and implications for landscape evolution of the Sierra Nevada (California): Geological Society of America Bulletin, v. 120, p. 274-299.

Busby, C. J. and Putirka, K., 2009, Miocene evolution of the western edge of the Nevadoplano in the central and northern Sierra Nevada: palaeocanyons, magmatism, and structure: International Geology Review, v. 51, p. 670-701.

Cassel, E. J. and Graham, S.A., 2011, Paleovalley morphology and fluvial system evolution of Eocene-Oligocene sediments ("auriferous gravels"), northern Sierra Nevada, California: Implications for climate, tectonics, and topography: Geological Society of America Bulletin, v. 123, p. 1699-1719.

Cassel, E. J., Graham, S. A., Chamberlain, C. P., Henry, C. D., 2012a, Early Cenozoic topography, morphology, and tectonics of the northern Sierra Nevada and western Basin and Range: Geosphere, v. 8, p. 229-249.

Cassel, E. J., Grove, M., and Graham, S. A., 2012b, Eocene drainage evolution and erosion of the Sierra Nevada batholith across northern California and Nevada: American Journal of Science, v. 312, p.117-144.

Cecil, M. R., 2006, Cenozoic exhumation of the northern Sierra Nevada, California, from 
(U-TH)/He thermochronology: Geological Society of America Bulletin, v. 118, p. 1481-1488.

Clark, M. K., Maheo, G., Saleeby, J., Farley, K. A., 2005, The non-equilibrium landscape of the southern Sierra Nevada, California: Geological Society of America Today, v. 15, p. 4-10, doi: 10:1130/1052-

5173(2005)015<4:TNELOT>2.0.CO;2.

Clark, W. B., 1965, Tertiary channels: Mineral Information Service, p. 39-44.

DeCelles, P. G., 2004, Late Jurassic to Eocene evolution of the Cordilleran thrust belt and foreland basin system, western U.S.A.: American Journal of Science, v. 304, p. 105-168.

DeGraaff-Surpless, K., Graham, S. A., Wooden, J. L., McWilliams, M. O., 2002, Detrital zircon provenance analysis of the Great Valley Group, California: Evolution of an arc-forearc system: Geological Society of America Bulletin, v. 114, p. 15641580.

Dickinson, W. R., Ingersoll, R. V., Graham, S. A., 1979, Paleogene sediment dispersal and paleotectonics in northern California: Geological Society of America Bulletin, v. 90, p. 1458-1528.

Ducea, M. N., 2001, The California arc: Thick granitic batholiths, eclogitic residues, lithospheric-scale thrusting, and magmatic flare-ups: Geological Society of America Today, v. 11, p. 4-10.

Durrell, C., 1966, Tertiary and Quaternary geology of the northern Sierra Nevada, in Bailey, E. H., editor, Geology of Northern California: California Division of Mines and Geology Bulletin 190, p. 185-197.

Figueroa, A. M. and Knott, J. R., 2010, Tectonic geomorphology of the southern Sierra Nevada mountains (California): Evidence for uplift and basin formation: Geomorphology, v. 123, p. 34-45.

Gabet, E. J., 2014, Late Cenozoic uplift of the Sierra Nevada, California? A critical analysis of the geomorphic evidence: American Journal of Science, v. 314, p. 1224-1257, doi:10.2475/08.2014.03.

Galewsky, J., 2009, Orographic precipitation isotopic ratios in stratified atmospheric flows: Implications for paleoelevation studies: Geology, v. 37, p. 791-794.

Garside, L. J., Henry C. D., Faulds, J. E., and Hinze, N. H., 2005, The upper reaches of 
the Sierra Nevada auriferous gold channels, California and Nevada, in Rhoden, H.N., Steininger, R.C., and Vikre, P.G., eds., Geological Society of Nevada Symposium 2005: Window to the World, Reno, Nevada, May 2005, p. 209-235.

Hietanen, A. M., 1976, Metamorphism and plutonism around the Middle and South Forks of the Feather River, California: U.S. Geological Survey Professional Paper 920, $38 \mathrm{p}$.

Henry, C. D., Hinz, N. H., Faulds, J. E., Colgan, J. P., John, D. A., Brooks, E. R., Cassel, E. J., Garside, L. J., Davis, D. A., and Castor, S. B., 2012, Eocene-Early Miocene paleotopography of the Sierra Nevada-Great Basin-Nevadaplano based on widespread ash-flow tuffs and paleovalleys: Geosphere, v. 8, p. 1-27.

Huber, N. K., 1981, Amount and timing of Late Cenozoic uplift and tilt of the central Sierra Nevada, California - Evidence from the upper San Joaquin River basin: U.S.G.S. Professional Paper 1197, 28 p.

Hudson, F. S., 1951, Mount Lincoln-Castle Peak area Sierra Nevada, California: Geological Society of America Bulletin, v. 8, p. 931-952.

Jarman, A., 1927, Report of the Hydraulic Mining Commission upon the feasibility of the resumption of hydraulic mining in California: State of California, a report to the Legislature of 1927; 23d Rept. State Mineralogist, p. 44-116.

Lindgren, W., 1911, The Tertiary gravels of the Sierra Nevada of California: U.S. G. S. Professional Paper 73, 226 p.

Mix, H. T., Ibarra, D. E., Mulch, A., Graham, S. A., and Chamberlain, C. P., 2015, A hot and high Eocene Sierra Nevada: Geological Society of America Bulletin, v. 128(3-4), p. 1047-1050.

Morris, P. A., 1966, A Field Guide to Pacific Coast Shells: Boston, Houghton Mifflin Company, $304 \mathrm{p}$.

Mueller, E. R., Pitlick, J., and Nelson, J. M., 2005, Variation in the reference Shields stress for bedload transport in gravel-bed streams and rivers: Water Resources Research, v.41, doi: 10.1029/2004WR003692.

Mulch, A., Graham, S. A., and Chamberlain, C. P., 2006, Hydrogen isotopes in Eocene river gravels and paleoelevation of the Sierra Nevada: Science, v. 313, p. 87-89.

Paes de Almeida, R., Marconato, A., Freitas, B. R., and Turra, B. B., 2016, The ancestors of meandering rivers: Geology, v. 44, p. 203-206. Doi: 10.1130/G37534.1. 
Palmer, C. M., 1978, Stratigraphy, petrology, and depositional environments of the Ione Formation in Madera County, California [Masters thesis]: Fresno, California State University, 99 p.

Palmer, C. M. and Merrill, R. D., 1982, Braided-stream and alluvial-fan depositional environments in the lower to middle Eocene Ione Formation, Madera County, California: Cenozoic nonmarine deposits of California and Arizona: Pacific Section, SEPM, 122 p.

Paola, C. and Borgman, L., 1991, Reconstructing random topography from preserved stratification: Sedimentology, v. 38, p. 553-565.

Paola, C. and Mohrig, D., 1996, Paleohydraulics revisited: Paleoslope estimation in coarse-grained braided rivers: Basin Research, v. 8, p. 243-254.

Peterson, D. W., Yeend, W. E., Oliver, H. W., and Mattick, R. E., 1968, Tertiary goldbearing channel gravel in northern Nevada County, California: Geological Survey Circular 566, 22 p.

Phillips, F. M., McIntosh, W. C., and Dunbar, N. W., 2011, Chronology of late Cenozoic volcanic eruptions onto relict surfaces in the south-central Sierra Nevada, California: Geological Society of America Bulletin, v. 123, p. 890-910.

Poage, M. A. and Chamberlain, C. P., 2002, Stable isotope evidence for a Pre-Middle Miocene rain shadow in the western Basin and Range: Implications for the paleotopography of the Sierra Nevada: Tectonics, v. 21, p. 1-9, doi: 10.1029/2001TC001303.

Saleeby, J., Pourhiet, L. L., Saleeby, Z., and Gurnis, M., 2012, Epeirogenic transients related to mantle lithosphere removal in the Sierra Nevada region, California, part I: Implications of thermomechanical modeling: Geosphere, v. 8, p.1286-1309. doi: 10.1130/GES00746.1.

Saucedo, G. J. and Wagner, D. L., 1992, Geologic map of the Chico quadrangle: California Division of Mines and Geology, scale 1:250,000.

Stock, G. M., Anderson, R. S., and Finkel, R. C., 2004, Pace of landscape evolution in the Sierra Nevada, California, revealed by cosmogenic dating of cave sediments: Geology, v. 32, p. 193-196.

Schweickert, R. A. and Cowan, D. S., 1975, Early Mesozoic tectonic evolution of the western Sierra Nevada, California: Geological Society of America, v. 86, p. 13291336. 
Wagner, D. L., Jennings, C. W., Bedrossian, T. L., and Bortugno, E. J., 1981, Geologic map of the Sacramento quadrangle, California: California Geological Survey, scale 1:250,000.

Wahrhaftig, C., 1965, Stepped topography of the southern Sierra Nevada, California: Geological Society of America Bulletin, v. 76, p. 1165-1190.

Wakabayashi, J., and Sawyer, T. L, 2001, Stream incision, tectonics, uplift, and evolution of topography of the Sierra Nevada, California: The Journal of Geology, v. 109, p. 539-562.

Whiting, P. J., Stamm, J. F., Douglas, B. M., and Orndorff, R. L., 1999, Sedimenttransporting flows in headwater streams: Geological Society of America Bulletin, v. 111 , p. $450-466$.

Yeend, W. E., 1974, Gold-bearing gravel of the ancestral Yuba River, Sierra Nevada, California: U.S.G.S. Professional Paper 772, 50 p.

Zachos, J., Pagani, M., Sloan, L., Thomas, E., and Billups, K., 2001, Trends, rhythms, and aberrations in global climate 65 Ma to present: Science, v. 292, p. 686-693. 


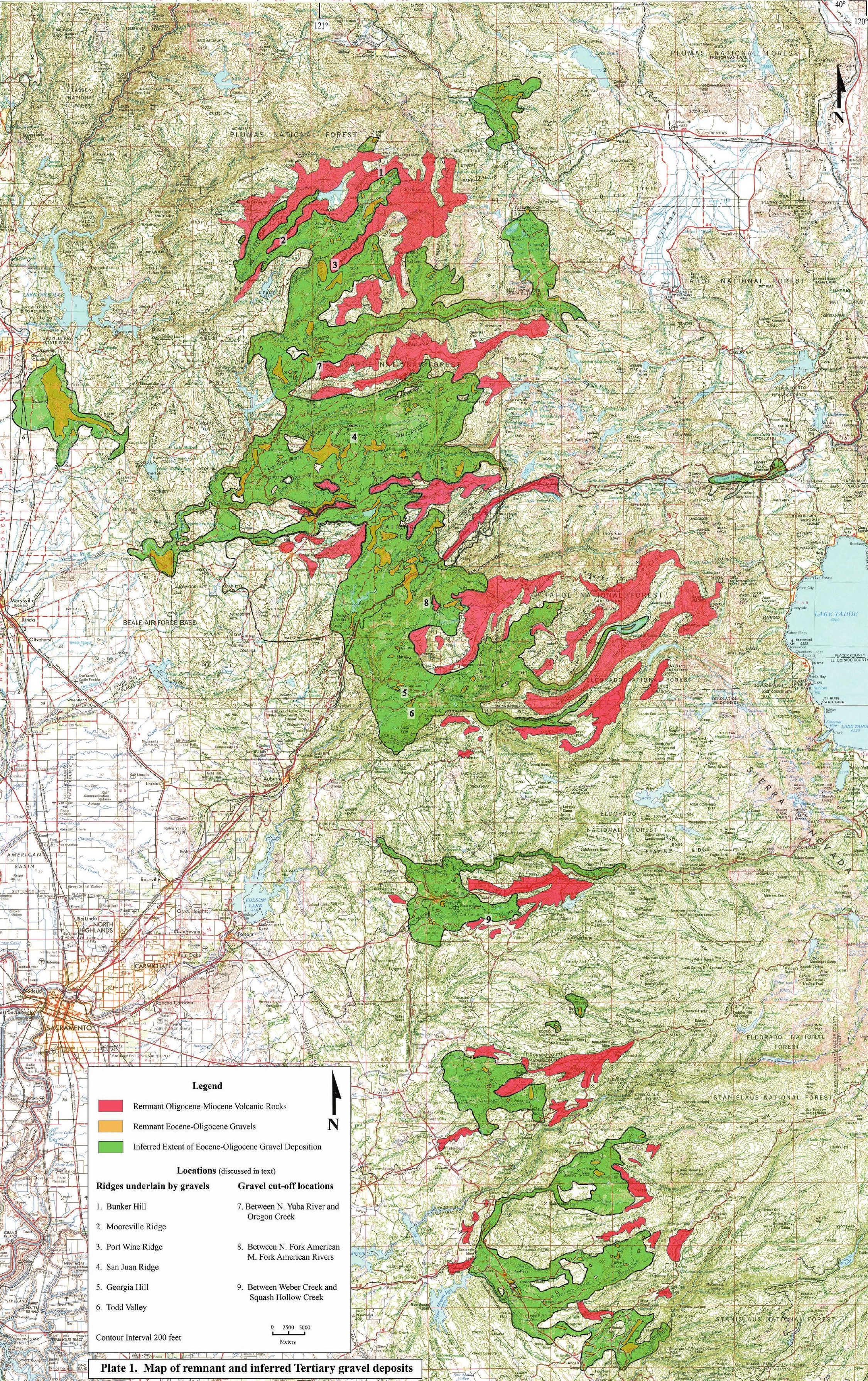




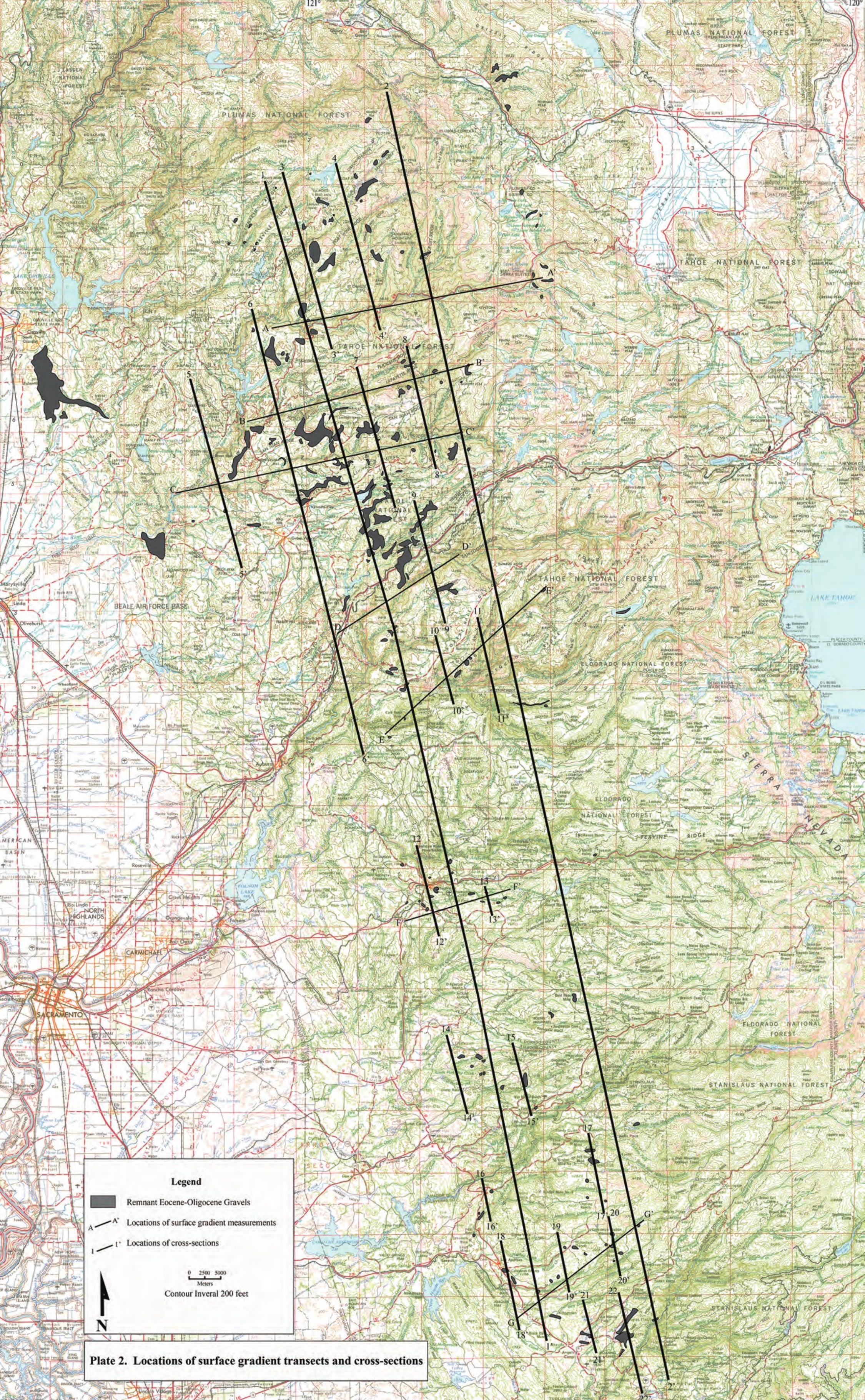

